\title{
SPECIES COMPOSITION AND FLIGHT PERIODS OF HORNTAIL WASPS (HYMENOPTERA: SIRICIDAE) WITHIN BASQUE COUNTRY PINE FORESTS, WITH THE CONFIRMATION OF ESTABLISHMENT OF THE EXOTIC SPECIES UROCERUS ALBICORNIS (FABRICIUS, 1781) IN NORTHERN SPAIN
}

\author{
A. Goldarazena \\ Qatar University, Department of Biological and Environmental Sciences, \\ College of Arts and Sciences, Qatar University, P.O.Box 2713, Doha, Qatar.
}

Corresponding author: alafuente@qu.edu.qa

\begin{abstract}
Species composition and flight periods of horntails wasps in Basque Country pine forests in northern Spain are studied in order to determine if alien invasive species have been introduced and established. Panel traps baited with Contech Inc. Sirex noctilio lures were erected at sites in six distinct Basque Country forest regions (Menagarai and Gordoa forests in Alava Province, Orio and Zegama forests in Gipuzkoa province and Carranza and Muxika forests in Bizkaia province). Traps were monitored throughout 2011 and 2012. At the same time in January, ten dead logs with oviposition holes from the same localities were collected and reared in emergence cages for wasp collection. In the pheromone traps three autochthonous, Palaearctic species were found: Sirex noctilio Fabricius, 1773, and Urocerus gigas (Linnaeus, 1758), and one exotic species Urocerus albicornis (Fabricius, 1781) was detected. From logs, the same three species plus U. augur (Klug, 1803) were obtained with a collection of parasitoids. Sirex noctilio, Urocerus gigas and Urocerus albicornis were found in all provinces of the Basque Country. Trapping results show flight occurs from late June to September. The establishment of $U$. albicornis, an exotic species from North America, is confirmed in northern Spain.
\end{abstract}

Keywords: invasive monitoring; woodwasps; Siricidae; flight period.

\section{RESUMEN}

Composición de especies y periodo de vuelo de las avispas de la madera (Hymenoptera: Siricidae) en los bosques de coníferas del País Vasco, con la confirmación del asentamiento de la especie exótica Urocerus albicornis (Fabricius, 1781) en el norte de España

El objetivo de este estudio fue determinar la composición de especies y el periodo de vuelo de las avispas de la madera en los bosques de coníferas del País Vasco (norte de España), para conocer si especies invasoras previamente introducidas se habían establecido. Trampas de interceptación tipo Panel cebadas con dispositivos Contech específicos para Sirex noctilio fueron colocadas en seis diferentes areas forestales del País Vasco (Menagarai y Gordoa en la provincial de Álava, Orio y Zegama en Gipuzkoa y Carranza y Muxika en Bizkaia). Las trampas fueron monitoreadas a lo largo de 2011 y 2012. Al mismo tiempo en enero, se recogieron de las mismas localidades 10 trozas con agujeros de oviposición y se mantuvieron en trampas de emergencia para la recolección de avispas. En las trampas de feromonas se encontraron dos especies autoctonas de distribución paleartica: Sirex noctilio Fabricius, 1773, Urocerus gigas (Linnaeus, 1758) y una especie exótica: Urocerus albicornis (Fabricius, 1781). De las trozas se encontraron las mismas tres especies más la especie U. augur (Klug, 1803) junto con una colección de parasitoides. Sirex noctilio, Urocerus gigas y Urocerus albicornis fueron encontrados en todas las provincias del País Vasco. Los resultados del trampeo mostraron que los sirícidos vuelan desde últimos de junio a septiembre. Se confirma el asentamiento de $U$. albicornis, una especie exótica de Norteamérica, en España.

Palabras clave: monitorización de especies invasoras; avispas de la madera; Siricidae; periodo de vuelo.

Recibido/Received: 16/10/2014; Aceptado/Accepted: 26/01/2015; Publicado en línea/Published online: 24/03/2015

Cómo citar este artículo/Citation: Goldarazena, A. Species composition and flight periods of horntail wasps (Hymenoptera: Siricidae) within Basque Country pine forests, with the confirmation of establishment of the exotic species Urocerus albicornis (Fabricius, 1781) in northern Spain. Grael/sia, 71(1): e020. http://dx.doi.org/10.3989/graellsia.2015.v71.121.

Copyright: (C) 2015 SAM y CSIC. Salvo indicación contraria, todos los contenidos de la edición electrónica de Graellsia se distribuyen bajo licencia de uso y distribución Creative Commons Reconocimiento no Comercial 3.0. España (cc-by-nc). 


\section{Introduction}

Invasive species constitute a growing problem in European and North American forests and can be a serious threat to forest sustainability (Ciesla, 2003; Roques, 2007). Despite efforts to combat introductions, the rate of establishment for exotic arthropods remains constant (Stendlid et al., 2007; Aukema et al., 2010). Regardless of ongoing introductions, little is known about the impact these pests may have on the forest ecosystem, and risk to these systems can be difficult to assess (Kenis et al., 2009). While many introduced forest insects pose little notable risk to forest stability, others, such as pine wilt nematode and processionary moth, are eliminating and damaging tree species in European forests.

\section{SIRICIDAE AS FORESTRY PESTS}

Members of Siricidae, commonly called horntails or woodwasps, are considered important, major forest pests (Viitasaari \& Heliövaara, 2004). Due to their symbiotic association and ability to vector wooddecaying fungi, some siricid wasps are able to kill trees. While ovipositing, females introduce the eggs along with the fungus and their own mucus, which possesses phytotoxic effects (Coutts, 1970), into the sapwood. Many horntail species are considered as secondary pests in their native range because they tend to attack weak or dying trees or trees that have recently died. However, when they are introduced into non-native countries, the economic, environmental and forestry impacts of these horntails can be greater. Biology of Siricinae is well documented in Europe (Viitasaari \& Heliovaara, 2004).

An invasive woodwasp, Urocerus albicornis, recently was added to the list of potential secondary forest pests in Spain as the result of several isolated interceptions in sawmills (Lopez et al., 2012). This species is native to North America, being present in Newfoundland to British Columbia, south to North Carolina, Michigan, Missouri, New Mexico, and California (Schiff et al., 2006). Due to timber importation to Europe, it has been also detected in the United Kingdom, the Netherlands, Iceland and Poland (Ólafsson, 1991; Liston, 1995; Witmond, 2001; Rasplus et al., 2010). However, its establishment in these countries is not fully confirmed due to insufficient data.

In North America, U. albicornis is reported to attack stressed or dead trees and does not cause excessive damage (Dodds et al., 2010). Conifers like Abies Mill., Larix Philip Miller, Picea (Dietr. A.) Link, Pinus L., Tsuga Carrière, Douglas-fir Pseudotsuga menziesii (Mirb.) Franco and western red cedar (Thuja plicata Donn ex D. Don) are listed as natural hosts in North America (Cameron, 1965; Schiff et al., 2006). Oviposition appears to take place in freshly cut or killed trees (Middlekauff, 1960) and the life cycle lasts 2 years (Belyea, 1952; Morris, 1967). Damage by larvae was described by Thomas (1881). In addition, Stillwell (1966) isolated the fungus Amylostereum (=Stereum) chailletii (Pers.) Boid. from the intersegmental sacs of $U$. albicornis reared in logs of Abies balsamea (L.) Mill. in New Brunswick and Nova Scotia, Canada. Several insect species are reported as parasitoids of $U$. albicornis in North America: Megarhyssa nortoni quebecensis (Provancher, 1873) (Hymenoptera: Ichneumonidae), Rhyssa lineolata (Kirby, 1837) and R. crevieri (Provancher, 1880) (Hymenoptera: Ichneumonidae), and Ibalia leucospoides (Hochenwarth, 1862) (Hymenoptera: Ibaliidae) (Middlekauff 1960; Cameron 1965; Schiff et al., 2012).

\section{Siricidae In FORESts of the Iberian Peninsula}

Little is known about the potential risk of the presence of $U$. albicornis in the Iberian Peninsula. Further studies are needed to know if it has been definitively established in the Basque Country, and on its ecology, focusing on the biology (e.g., flight period, hosts, development) and the presence of potential parasitoid species. U. albicornis is regarded as a secondary pest in its native range (Schiff et al., 2012) and there are no reports of damage caused by $U$. albicornis in Europe. However, as mentioned above, the association with $A$. chailletii has been reported in its natural distribution range (Wilson et al., 2009). It should be taken into account that a possible lack of defensive mechanisms of native host trees outside the pests natural distribution range may make them susceptible to $U$. albicornis infestation, and therefore this pest in a new host range may represent a serious threat as was the case with $S$. noctilo in Australia, South America and South Africa. Thus, the detection of wood-decaying fungi associated with $U$. albicornis should be stated as a critical point in order to assess the real risk of its presence. Moreover, additional work is needed to study in greater depth the biology of this insect in its new distribution, notably what kinds of trees are attacked (e.g., healthy or decaying). This information will allow determination of the role of $U$. albicornis as a potential forestry pest.

A first step in investigating Siricidae is to gain an understanding of species composition and flight periods in pine forests that are likely to be colonized by U. albicornis. Forest insects' emergence and flight periods can be influenced by weather and factors such as temperature can cause a change in phenology between populations of the same species (Jepsen et al., 2011). Warmer temperatures can have an indirect effect by stimulating growth in pines and a direct effect by increasing insect metabolism (Thomson et al., 2010). The biology of Siricidae has been poorly studied in the Iberian Peninsula and no species have been documented within the Basque Country. Fauna Europaea (2013) listed eight Urocerus and six Sirex 
species in Europe. To date, for the Iberian Peninsula Urocerus has been represented by four species, i.e., Urocerus gigas, Urocerus fantoma (Fabricius, 1781), U. albicornis and Urocerus augur (Ceballos Jiménez, 1963; Lopez et al., 2012). Sirex is represented by one species, Sirex noctilio.

The objective of this study is to determine the species composition and flight period of native Siricidae within Basque Country pine forests and to confirm the status of $U$. albicornis. Knowing flight periods for native Siricidae can eventually lead to an understanding of dispersal, inter-species interactions and oviposition behavior.

\section{Material and methods}

SITES

Two sites were chosen in pine forests within each province. Sirex lures were erected at sites in six distinct Basque Country forest regions (Menagarai and Gordoa forests in Alava Province, Orio and Zegama forests in Gipuzkoa Province and Carranza and Muxika forests in Bizkaia Province). Traps were monitored throughout 2011 and 2012. At the same time in January of both years, ten dead logs with oviposition holes from the same localities were collected and placed in emergence cages for wasp emergence.

Logging occurred within each site in the summer or fall of 2010 and much of the slash was left in the sites through the 2011 and 2012 siricid collecting seasons. These stands in the sites were mostly pine with a component of hardwoods (Crataegus spp., Ilex spp., Acer spp., Rubus spp.) mainly in the understory. These stands had a mixture of tree age and diameter. Pines within the stands were Monterrey pine (Pinus radiata $\mathrm{D}$. Don.). These sites ranged from moderately to heavily managed stands and two points were randomly selected in each site.

\section{TRAPPING IN THE FIELD}

Siricids were collected at each site with three interception traps baited with Contech Inc. Sirex lure ( $\alpha-\beta$ pinene) plus $95 \%$ high-release ethanol (Fig. 1). Flight traps were used because it is suggested that they outperform Lindgren funnel traps in capturing large bodied insects, such as siricids (Johnson et al., 2009). The traps were $70 \mathrm{~cm}$ long and $25 \mathrm{~cm}$ wide and hung $1 \mathrm{~m}$ above the ground. Trapped specimens were captured in propanodyol in a collection container at the bottom of the trap. Traps were placed approximately $40 \mathrm{~m}$ apart at each site. Trapping was initiated from late April to early December in 2011 and 2012. Trap catches were collected every two weeks until early December in both years. Lures were changed according to manufacturer recommendations, approximately once every 4 weeks.

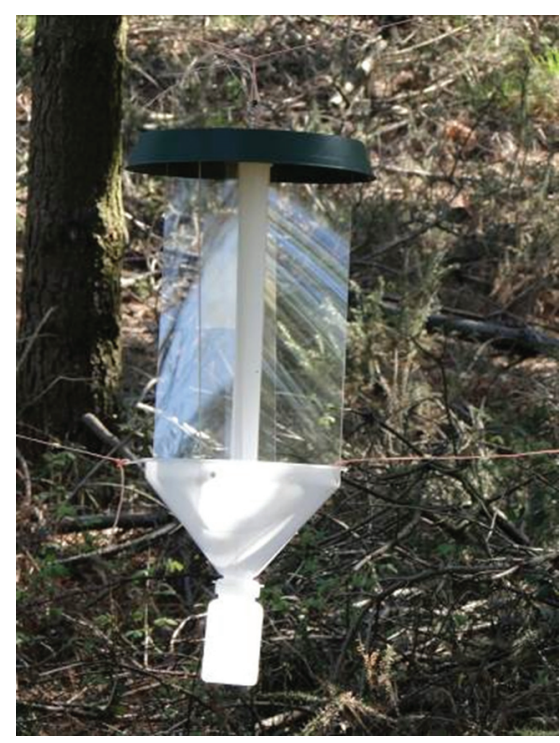

Fig. 1.- Flight trap.

Fig. 1.- Trampa de interceptación de vuelo.

All trap catches were transferred into plastic vials in the field, brought back to the lab and stored at $1{ }^{\circ} \mathrm{C}$. Specimens from each trap were categorized as siricids, parasitoids, and large and small arthropods. Each group was stored in separate vials in $95 \%$ ethanol. Siricids were further identified to species using the manual of Schiff et al. (2006, 2012), Benson (1943) and Gussakovskij (1935). Each specimen was placed in a separate vial and labeled with an identification number, site, trap, and collection date and entered into a database.

Emergence traps: From the stands where the traps were set up, I examined large numbers of dead and dying trees for symptoms of occupancy by Siricidae. In January 2012, 10 fallen logs were selected from each sampling site (60 logs total), with emergence holes that could have been produced by siricids according with Ayers et al. (2009) (Fig. 2). The logs were transported to a covered storage building without heating and introduced individually into hard paper barrels opened with an entomological cloth (Fig. 3). The barrels were checked twice a week from late March to the end of June, and all the insects

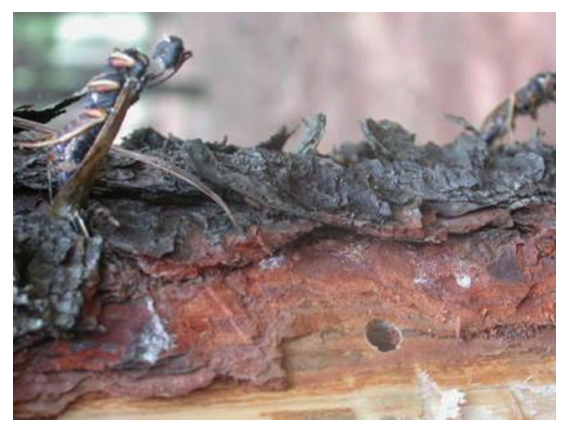

Fig. 2.- Emergence holes of Urocerus albicornis.

Fig. 2.- Orificios de emergencia de Urocerus albicornis. 


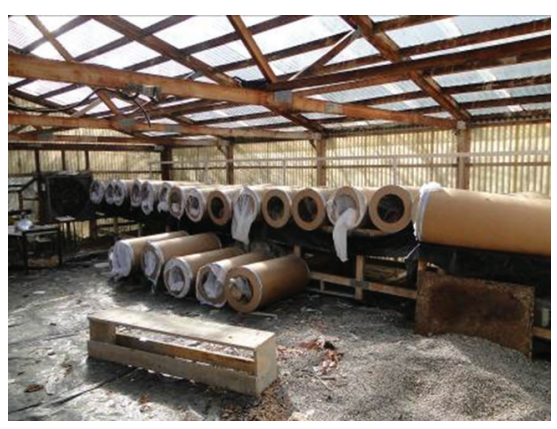

Fig. 3.- Emergence traps.

Fig. 3.- Trampas de emergencia.

were collected alive and stored in vials. The rate of parasitism of siricid wasps was calculated using the following formula:

$\%=$ Number of emerged parasitoids $\times 100 /$ (number of emerged parasitoids + number of siricids emerged).

\section{COLlection STUdies}

Collections of Hymenoptera of the Entomological Societies of Galicia, Cantabria and Asturias (Northern Spain provinces) also were studied to determine the presence of $U$. albicornis.

\section{Results}

\section{SIRICID TRAPPING}

In 2011, 27 U. albicornis, 7 Sirex noctilio, 4 Urocerus gigas, and 1 Xeris spectrum were caught in traps at 6 sites in the Basque Country (Table 1). In 2012, 17 U. albicornis, 7 S. noctilio, 6 U. gigas and, 2 Xiphydria camelus were caught in traps at the same sites.

\section{EMERGENCE TRAPS}

In 2011, 263 (186 males and 77 females) U. albicornis, 3 (2 males and 1 female) S. noctilio, 3 (2 males and 1 female) $U$. augur and 17 (10 males and 7 females) $U$. gigas emerged from the logs stored in the emergence traps (Table 2). Two siricid parasitoids were collected, 27 specimens of Ibalia leucospoides, and 22 specimens of Rhyssa persuasoria (Linnaeus, 1758).

\section{Collection studies}

Two females identified as Urocerus albicornis are in the collection of the Entomological Society of Galicia Province. The specimens were captured in Lugo in 2012 in a cultivated forest of Pinus radiata.

\section{Discussion}

Four siricids were collected from these regions, Sirex noctilio, Urocerus augur, Xeris spectrum, and Urocerus albicornis, and one xiphydriid, Xiphydria camelus (Linnaeus, 1758) The four siricids trapped colonize pines and thus responded to Sirex lures during both years. Xiphydria camelus is a hardwood specialist and thus would not be attracted to the Sirex lures. However, each site had a minority hardwood component and the addition of an ethanol lure could have attracted this species or they were passively trapped. All these species are Palaearctic except $U$. albicornis which is Nearctic. All the specimens of $S$. noctilio and $U$. gigas trapped with lures in both years were female, although natural populations of $U$. albicornis seems to have a male-biased sex ratio since 32 males and 12 females were trapped. This is usual in siricid wasps according to the studies of Morgan \& Stewart (1966) and Morgan (1968). Differences in numbers of $U$. albicornis trapped among regions were not the same in both years, but most specimens were collected during the summer. Urocerus gigas was trapped mainly in July and $S$. noctilio was trapped in September (Fig. 4).

U. albicornis (Fig. 5) is an exotic horntail native to North America and was discovered in Spain in 2012 (Lopez et al., 2012). Samples of males and females were obtained unintentionally during surveys for Ips sexdentatus using multiple funnel traps baited with an I. sexdentatus-specific attractant in different sawmills and timber processing industries of Basque Country (Northern Spain) during 2003 and 2011. However, its establishment in Spain was not fully confirmed due to insufficient data. During our sampling, 263 specimens were collected while emerging from the logs taken in the three provinces of the Basque Country. We observed that $U$. albicornis was the most abundant

Table 1.- Woodwasp collected in a Flight traps baited with lures of Sirex noctilio, Spain, January to December 2011-2012.

Tabla 1.- Sirícidos capturados en trampas de interceptación de vuelo cebadas con atrayentes de Sirex noctilio, España, enero a diciembre 2011-2012.

\begin{tabular}{lcccccc}
\hline Woodwasp collected in Lindgren funnel traps & Menagarai & Gordoa & Orio & Zegama & Carranza & Muxika \\
\hline Urocerus albicornis & 6 & 15 & 7 & 4 & 3 & 9 \\
Sirex noctilio & 3 & 0 & 3 & 2 & 4 & 2 \\
Urocerus gigas & 1 & 1 & 2 & 2 & 1 & 3 \\
Xiphydria camelus & 0 & 0 & 1 & 0 & 0 & 1 \\
Xeris spectrum & 0 & 0 & 0 & 0 & 0 & 1 \\
\hline
\end{tabular}


Table 2.- Hymenoptera collected in emergence traps.

Tabla 2.- Himenópteros capturados en trampas de emergencia.

\begin{tabular}{lcccccc}
\hline Woodwasp collected in emergence traps & Menagarai & Gordoa & Orio & Zegama & Carranza & Muxika \\
\hline (12) Urocerus albicornis & 59 & 78 & 36 & 25 & 30 & 35 \\
$\quad$ Urocerus gigas & 5 & 10 & 1 & 0 & 1 & 0 \\
Urocerus augur & 0 & 3 & 0 & 0 & 0 & 0 \\
Sirex noctilio & 1 & 1 & 0 & 0 & 1 & 3 \\
(13) Ibalia leucospoides & 0 & 23 & 0 & 0 & 4 \\
(14) Rhyssa persuasoria & 16 & 0 & 0 & 0 & & 4 \\
\hline
\end{tabular}

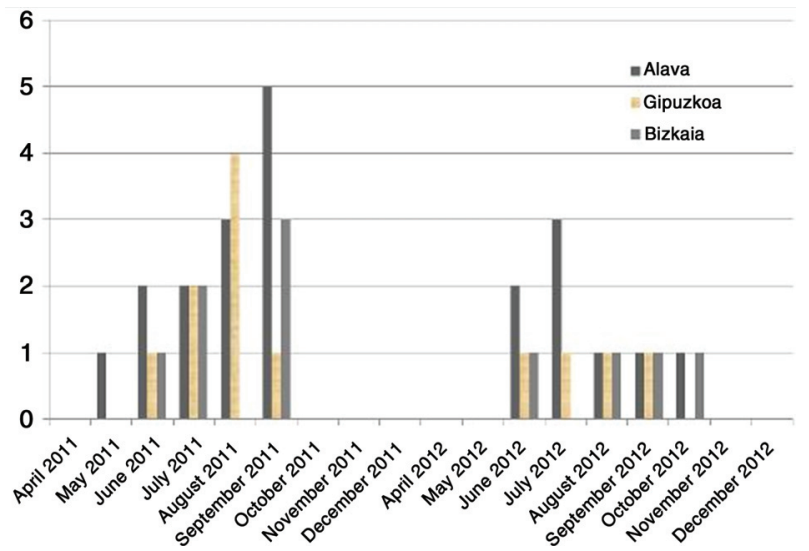

Fig. 4.- Flight periods of Urocerus albicornis during 2011-2012.

Fig. 4.- Periodos de vuelo de Urocerus albicornis durante 2011-2012.

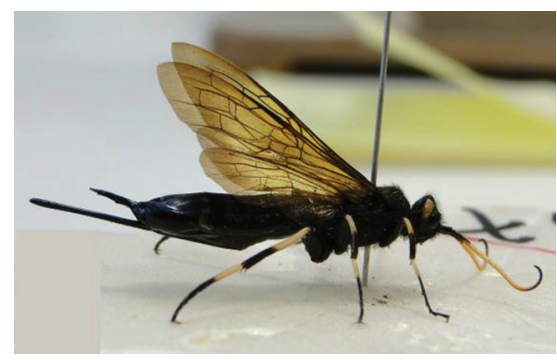

Fig. 5.- Urocerus albicornis emerged female from infested logs.

Fig. 5.- Hembra de Urocerus albicornis emergida de las trozas infectadas.

horntail emerging from the logs. During the experiment, 186 males and 77 females were captured in the nets of the emergence traps. We also observed that one $\log$ can be inhabited by both species of Urocerus at the Gordoa (Alava Province) site. Most of the specimen emerged from the logs in May and June. The presence of $U$. albicornis in Galicia Province $(1000 \mathrm{~km}$ east from the Basque Country) indicates that this exotic species is probably widely distributed throughout Northern Spain.

Urocerus albicornis is attacked by the same parasites of $S$. noctilio and $U$. gigas. Adults of Rhyssa persuasoria emerged from middle April to the end of May while Ibalia leucospoides emerged from June to the end of July. These data agree with Spradbery (1970) and Spradbery \& Kirk (1978) who studied the life cycle of the parasites. Percentages of parasitism varied from 0\% (Zegama and Orio), 28\% (Muxika), 35\% (Menagarai), 39\% (Gordoa) and 41\% (Carranza).

Populations of species of Siricidae remain at low density in their native ranges, and the insect is considered as a secondary pest. This is in contrast to the invaded areas, where the insect populations are large and they have resulted in serious and damaging outbreaks (Boissin et al., 2012). According to my preliminary data, the density of this invasive species could follow this rule and must be monitored in the future for potential outbrakes that could produce negative economic impacts in our coniferous forests. Much effort is needed to avoid the introduction of this invasive species in the Iberian Peninsula, especially at seaports during the transportation of logs from the Americas and other continents.

\section{Acknowledgements}

The technical assistance of Patxi Saenz de Urturi and Ander Isasmendi (The Basque Institute for Agricultural Research and Development, Neiker-Tecnalia) is greatly appreciated. Special thanks to Juan Carlos Pino (Diputación Foral de Bizkaia, Forestry Department) for searching sampling sites. I thank Bernard Slippers for sending literature. Financial support for this study was provided by the Spanish Ministry of Science and Education through cooperative agreement No. AGL2009-13452-C02-01.

\section{References}

Aukema, J. E., McCullough, D. G., Von Holle, B., Liebhold, A. M., Britton, K. \& Frankel, S. J., 2010. Historical accumulation of non indigenous forest pests in the continental United States. BioScience, 60: 886-897. http:// dx.doi.org/10.1525/bio.2010.60.11.5.

Ayres, M. P., Sullivan, J. M., Harrison, T. \& Lombardero, M., 2009. Diagnosing the presence of Sirex noctilio from examination of dying and recently dead pines trees. Report from USDA APHIS. www.dartmouth. edu/ mpayres/pubs/SirexDiagnostics.pdf.

Belyea, R. M., 1952. Death and deterioration of balsam fir weakened by spruce budworm defoliation in Ontario. The Canadian Entomologist, 84: 325-335. http://dx.doi. org/10.4039/Ent84325-11. 
Benson, R. B., 1943. Studies in Siricidae, especially of Europe and southern Asia (Hymenoptera; Symphyta). Bulletin of Entomological Research, 34(1): 27-51. http://dx.doi.org/10.1017/S0007485300023464.

Boissin, E., Hurley, B., Wingfield, M. J., Vasaitis, R., Stendlid, J., Davis, C., De Groot, P., Ahumada, R., Carnegie, A., Goldarazena, A., Klasmer, P., Wermelinger, B. \& Slippers, B., 2012. Retracing the routes of introduction of invasive species: the case of the Sirex noctilio woodwasp. Molecular Ecology, 21: 5728-5744. http://dx.doi.org/ $10.1111 / \mathrm{mec} .12065$.

Cameron, E. A., 1965. The Siricinae (Hymenoptera: Siricidae) and their parasites. Commonwealth Institute of Biological Control, Technical Bulletin, 5: 1-31.

Ceballos Jiménez, P., 1963. Sirícidos españoles (Himenoptera). Graellsia, 20: 55-67.

Ciesla, W., 2003. European woodwasp: a potential threat to North America's conifer forests. Journal of Forestry, 101: 18-23.

Coutts, M. P., 1970. The physiological effects of the mucus secretion of Sirex noctilio on Pinus radiata. Australian Forestry Research, 4: 23-26.

Dodds, K. J., De Groot, P., David, A. \& Orwig, D. A., 2010. The impact of Sirex noctilio in Pinus resinosa and Pinus sylvestris stands in New York and Ontario. Canadian Journal of Forest Research, 40: 212-223. http://dx.doi. org/10.1139/X09-181.

Fauna Europaea, 2013. Fauna Europaea version 2.4. http:// www.faunaeur.org [accessed on 05 September 2014].

Gussakovskij, V. V., 1935. Insectes Hyménoptères, Chalastogastra 1. Fauna SSSR, vol. 2(1). Moskva-Leningrad. $453 \mathrm{pp}$.

Jepsen, J. U., Kapari, L., Hagen, S. B., Schott, T., Vindstand, O. P. L., Nilssens A. C. \& Ims R. A., 2011. Rapid northwards expansion of a forest insect pest attributed to spring phenology matching with sub-Arctic birch. Global Change Biology, 17: 2071-2083. http://dx.doi. org/10.1111/j.1365-2486.2010.02370.x.

Johnson, W. J., Meeker, R. \& Ross, W. G., 2009. Improved detection and monitoring systems for native and nonnative siricids. USDA Forest Service STDP Final Report. R8-2005-01.

Kenis, M., Auger-Rozenberg, M., Roques A., Timms L., Péré C., Cock, M. J. W., Settele, J., Augustin, S. \& López-Vaamonde, C., 2009. Ecological effects of alien insects. Biological Invasions, 11: 21-45. http://dx.doi. org/10.1007/s10530-008-9318-y.

Liston, A. D., 1995. Compendium of European Sawflies. List of species, modern nomenclature, distribution, foodplants, identification literature. Chalastos Forestry. Gottfrieding. 190 pp.

López, S. L., González, M. \& Goldarazena, A., 2012. Urocerus albicornis (Fabricius, 1781) (Hymenoptera: Siricidae), a new exotic horntail for the Iberian Peninsula. Bulletin OEPP/EPPO Bulletin, 42: 150-153. http://dx.doi.org/10.1111/epp.2543.

Middlekauff, W. W., 1960. The siricid wood wasps of California (Hymenoptera: Symphyta). Bulletin of the California Insect Survey, 6: 59-77.
Morgan, F. D., 1968. Bionomics of Siricidae. Annual Review of Entomology, 13: 239-256.

Morgan, F. D., Stewart, N.C., 1966. The biology and behaviour of the woodwasp Sirex noctilio (F.) in New Zealand. Transactions of the Royal Society of New Zealand Zoology, 7: 195-204.

Morris, E. V., 1967. Distribution and hosts of some horntails (Siricidae) in British Columbia. Journal of Entomological Society of British Columbia, 64: 60-63.

Ólafsson, E., 1991. [A checklist of Icelandic insects.] Fjölrit Náttúrufrceðistofnunar, 17: 1-69 (in Icelandic).

Rasplus, J.-Y., Villemant, C., Paiva, M. R. \& Roques, A., 2010. Hymenoptera. Chapter 12. BioRisk, 4: 669-776. http://dx-doi.org/10.3897/biorisk.4.55.

Roques, A., 2007. Old and new pathways for invasion of exotic forest insects in Europe. In: H. Evans \& T. Oszako (eds.). Alien invasive species and international trade. Forest Research Institute. Warsaw: 80-88.

Schiff, N. M., Goulet H., Smith D. R., Boudreault C., Wilson A. D. \& Scheffler B. E., 2012. Siricidae (Hymenoptera: Symphyta: Siricoidea) of the Western Hemisphere. Canadian Journal of Arthropod Identification 21: 1-305.

Schiff, N. M., Valley, S. A., LaBonte, J. R. \& Smith, D. R., 2006. Guide to the Siricid Woodwasps of North America. US Department of Agriculture, Forest Health Technology FHTET-2006-15, Enterprise Team. Morgantown. $102 \mathrm{pp}$.

Spradbery, J. P., 1970. The biology of Ibalia drewseni Borries (Hymenoptera: Ibaliidae), a parasite of siricid woodwasps. Proceedings of the Royal Entomological Society of London (A), 45: 104-113. http://dx.doi. org/10.1111/j.1365-3032.1970.tb00707.x.

Spradbery, J. P. \& Kirk, A. A., 1978. Aspects of the ecology of siricid woodwasps (Hymenoptera: Siricidae) in Europe, North Africa, and Turkey with special reference to the biological control of Sirex noctilio $\mathrm{F}$. in Australia. Bulletin of Entomological Research, 68: 341-359. http://dx.doi.org/10.1017/ S0007485300009330.

Stendlind, J., Santini, A., Vanninim A., Capretti, P. \& Vasiliauskas, R., 2007. FORTHREATS: European network on emerging diseases and invasive species threats to European forest ecosystems. In: F. Lieutier, K. R. Day, A. Battisti, J.-C. Grégoire \& H. F. Evans (eds). Bark and Wood Boring Insects in Living Trees in Europe, a Synthesis. Kluwer Academic Press. Dordrech: 529-534.

Stillwell, M. A., 1966. Woodwasps (Siricidae) in Conifers and the Associated Fungus, Stereum chailletii, in Eastern Canada. Forest Science, 12: 121-128.

Thomas, C., 1881. Uroceridae. Report of the State Entomologist on the noxious and beneficial insects of the state of Illinois, 10: 70-71.

Thomson, L. J., Macfadyen, S. \& Hoffmann, A. A., 2010. Predicting the effects of climate change on natural enemies of agricultural pests. Biological Control, 52: 296-306. http://dx.doi.org/10.1016/j.biocontrol.2009. 01.022 . 
Viitasaari, M. \& Heliövaara, K., 2004. Non-coleopteran insects. Siricidae (Horntails). In: F. Lieutier, K. R Day, A. Battisti, J.-C. Grégoire \& H. F. Evans (eds.). Bark and Wood Boring Insects in Living Trees in Europe, a Synthesis. Kluwer Academic Press. Dordrech: 501-539.

Wilson, A. D., Schiff, N. M. \& Haugen, A., 2009. First report of Amylostereum areolatum in pines in the United
States. Plant Disease, 93: 108. http://dx.doi.org/10.1094/ PDIS-93-1-0108A.

Witmond, L., 2001. An addition and correction to the list of Urocerus species occurring in the Netherlands (Hymenoptera: Siricidae). Entomologische Berichten, 61: 30-32. 